This is the final peer-reviewed accepted manuscript of:

Panvini G. (2019) Third Worldism in Italy. In: Berger S., Cornelissen C. (eds) Marxist Historical Cultures and Social Movements during the Cold War. Palgrave Studies in the History of Social Movements. Palgrave Macmillan, Cham. https://doi.org/10.1007/978-3-030-03804-5 12

The final published version is available online at:

https://link.springer.com/chapter/10.1007/978-3-030-03804-

$5 \quad 12$

Rights / License:

The terms and conditions for the reuse of this version of the manuscript are specified in the publishing policy. For all terms of use and more information see the publisher's website.

This item was downloaded from IRIS Università di Bologna (https://cris.unibo.it/)

When citing, please refer to the published version. 


\section{Third Worldism in Italy}

Guido Panvini

\section{INTRODUCTION}

Third Worldism has not yet received sufficient attention in the Italian historiographical debate, especially as regards the 1960s and 1970s. Much specific research has been done on individual aspects of a phenomenon that in reality is very complex and structured. Most of these studies have in fact focused on the workers' and students' protests of 19681969, but without thoroughly investigating the various cultural origins that marked this period of political and social clashes. One is the Third Worldism tradition that firmly established itself in Italy between the late 1950s and the beginning of the following decade.

We are therefore still very far from a sure definition of the category of Third Worldism, despite the results achieved in the field of archive research. Suffice it to say that the historiographical debate on Italian Marxism of the 1960s and 1970s concentrated almost exclusively on 
Workerism and neglected this cultural movement, despite of the fact that it played a crucial role in renewing the Marxist culture of those years.

This absence is peculiar for many reasons-all the more so if we compare it with the attention given to Third Worldism in other historiographical reflections, starting with the Anglo-Saxon and German ones.

In fact, Third Worldism falls within a wider ranging discussion on imperialism and colonialism that ran through the history of the socialist and workers' movements in the twentieth century. It can be said that this is the last reflection of an intellectual tension that has come from afar. Beginning with the rift within the Western reformist and socialdemocrat parties in the late nineteenth century, regarding whether or not to counteract the imperialist policies of the major European powers, right up to the theoretical splits introduced within Marxism by Rosa Luxemburg and Lenin on the relationship between imperialism and colonialism.

In this chapter it is not possible to examine such a long and complex history. It is sufficient to mention the consequences of World War I on the socialist movement, the role played by Third International in supporting the struggle of colonial populations, the victory of the revolution in China in 1949, the revolution of Nasser in Egypt in 1952, the birth of pan-Arabic anti-colonialism, the war in Indochina that ended in 1954 with the defeat of the French, the Afro-Asian Conference in Bandung in 1955, the decolonization movements in Africa, the Algerian War, and the guerrilla warfare in Latin America during the 1950s and 1960s.

In other words, a long chain of events that caused great consequences within international communism. Indeed, from the end of World War II on, Soviet communism still retained the character of a Eurocentric movement. Instead, it was the anti-colonial thrust coming from the Third World that caused the spread of the anti-imperialist message, which had always been linked to the myth of the Bolshevik Revolution within emerging nations.

The Soviet Union was seen as a deterrent against the colonial powers and at the same time a possible model for modernization. And so the aid policy toward the Third World became a peculiar feature of the Soviet strategy, beginning in the second half of the 1950s. In Khrushchev's opinion peaceful coexistence in the West, for example, had to be accompanied by a growing attention toward countries outside Europe, considered as the main arena for challenging Western capitalism. 
In 1959 the Cuban Revolution further confirmed this direction of travel. The Cold War, in short, had resulted in a radical change in meaning within the international communist movement and consequently also within Marxist paradigms. The Sino-Soviet split caused further changes.

Despite this overall picture the historiographical reflection within Italian Marxism on the link between communism, Third Worldism, and the political and social conflict in the 1960s and 1970s, as already mentioned, seems to be minimal.

The origin of this omission also lies in the fact that the expressions Third World and Third Worldism were born within French sociology and demography of the early 1950 s to describe the processes of decolonization and the rise of new nations under way at that time in Africa, Asia, and Latin America.

And what was meant by these expressions depended on very different phenomena: from the question of "non-alignment" with the development strategies of emerging countries, from guerrilla movements, to movements claiming economic rights in more or less institutionalized relations with the international system.

\section{The Third Worldism of Intellectuals}

It is necessary to dwell albeit briefly on the different cultural origins of the Italian Third Worldism present within the political and intellectual debate beginning at least in the very early 1960s.

There is, for example, a Third Worldism of intellectuals linked to the world of culture. It's enough to think of the role played by the Einaudi publishing house in distributing the writings of Frantz Fanon whose The Wretched of the Earth-a crucial book we will talk about later-was published in Italy in 1962, with a foreword by Jean-Paul Sartre.

The translation and distribution of Fanon's books were possible, moreover, thanks to one of the most eccentric figures of the Italian intellectual scene in the 1960s: Giovanni Pirelli. Together with Pirelli it is also necessary to mention Franco Fortini and the film director Gillo Pontecorvo who, thanks to his film The Battle of Algiers (1965), helped to spread Third Worldism far beyond national borders. 
Another Third Worldism with an intellectual origin developed at the margins of or outside historical left-wing parties. Various journals, like Problems of Socialism, of which Lelio Basso was the editor in chief, featured numerous articles on this topic. ${ }^{1}$ There were also a great many periodicals, particularly in the second half of the 1960s, that helped to make the theses of Castro and Guevara common knowledge.

The magazine La Sinistra, for example, springs to mind. It was inspired by Trotsky's views but leant toward the Cuban Revolution. This magazine went on to play a major role in the radicalization of the student movement in 1968. ${ }^{2}$ There was also the Maoist microcosm that was extremely active in spreading the struggles for national liberation in the Third World.

Third Worldism represented therefore a structured and very heterogeneous intellectual movement. In fact, it reflected the expressions of a much more extensive rebellion causing the wars, revolutions, and guerrilla warfare that had taken place in Asia, Africa, and Latin America beginning in the second half of the 1950s.

To this we must add finally the influence of the movement for the liberation of Palestine in the shaping of a radical Third Worldism that would mark the political culture of the radical left in the 1960s. It was, however, the Third Worldism of Catholic origin that exerted the greatest influence on extra-parliamentary movements, contaminating the Marxist theoretical view itself.

\section{Third Worldism of a Catholic Origin}

On April 25, 1961, during a political rally in Florence, Enrico Mattei commemorated the anniversary of Italy's liberation with these words:

Freedom, before being the essence of political life, is an inner virtue, a prerogative of the spirit, which is preserved and strengthened through ceaseless vigilance and moral rigour. If we widen our gaze to other lands ... we see peoples beyond the seas, who today are still fighting for freedom.

${ }^{1}$ L. Basso (1961) 'Cuba repubblica socialista', Problemi del socialismo, p. 5.

${ }^{2}$ La Sinistra (1967) 'Il socialismo di Fidel', pp. 4-5. 
We feel close to them, precisely because our experience has made us particularly sensitive to this duty of human understanding. Wherever an invasion is attempted, wherever small tyrants or great powers, threaten to suffocate human freedom, our reaction can only be one of condemnation. $[\ldots]$

The forces of political immobility, the allies of economic privileges, with the convenient mentality of the age-old conservatives, shout against the rebellious spirit of these populations. They are rebels, or fellow partisans, it's true, just as we were when we were forced to rebel against injustice, tyranny and oppression, for the sacrosanct defence of human rights, and we are convinced that when a people, whether white or coloured, fights with all their soul for their freedom, God is their ally. ${ }^{3}$

Mattei, therefore, was tracing an ideal bond between decolonization movements and the anti-fascist resistance. This interpretation was a reflection in part of the foreign policies decided by the leaders of the Christian democrats. Ever since the end of World War II the Italian diplomatic corps had tried to carve out an international niche for itself, while not calling into question its bond with the United States and the Atlantic Alliance.

Amintore Fanfani had played a key role in combining compliance with these bonds with the search for a new leading role for Italy in the concert of nations. In 1956 condemnation of the Soviet invasion of Hungary and the Anglo-French invasion of Egypt indicated the strength of Italy's relationship with the United States and at the same time the desire to establish itself as a privileged interlocutor of emerging countries.

The decolonization process and the awakening of the Arab world represented an opportunity that could not be missed: the concern of the United States regarding Soviet penetration in the Mediterranean and the Middle East and it distancing itself from the colonial resurgence of France and England coincided in fact with the desire of various Italian governments to carve out an influential space for themselves in those areas.

${ }^{3}$ E. Mattei (1963) 'Il suo testamento', Europa Libera, p. 13. 
Added to this was the expansion strategy of ENI, an energy company led by Enrico Mattei from 1953 to 1962 . The goal to become self-sufficient in energy and free itself from the global oil markets drove ENI to establish close ties with countries in the Middle East that were oil producers and were by then intolerant of the international oil giants that managed the production processes and used the profits of the "black gold" largely for their own advantage.

Having found another interlocutor favored the thrust for independence so much so that Mattei presented his plan as an attempt to free Italy from the very same powers that were subjugating the emerging countries of the Third World.

Mattei represented an important part of what was called neo-Atlanticism, the direction that Italian foreign policy had taken in an attempt to redefine the bond with the United States through an active role for Italy in the Mediterranean and Middle East.

It was not a coincidence that the main figures in this new orientation were Fanfani (the political godfather of the President of ENI), La Pira, and the Christian democrat left. They were convinced that anti-communism should not be transformed into a frontal collision with the Soviet Union, but instead into a careful policy of cultural and economic penetration in areas where there was competition with communist countries.

These were the premises of the dialogue begun by the leaders of the Christian Democrats with the Arab nationalist regimes and with the revolutionary movements in the Middle East, a dialogue that would continue in subsequent years. With the Arab-Israeli war of 1967, the socalled Six-Day War, the Christian Democrats opted for an equidistant stance and support for the United Nations' role as mediator. This choice reiterated and relaunched by Aldo Moro would later expose Italy to the tensions caused by the wars that marked the Mediterranean and Middle East in the following years.

There and then the pro-Arab position of the Christian democrat leaders corresponded with the way the ranks of social Catholicism and Christian partisan associationism regarded the links between the struggles for liberation in the Third World and the Résistance. Such an analogy could significantly be identified between the conditions of submission being fought against by African, Asian, and Eastern European countries under communist domination, defined as "colonies" of the Soviet Union. ${ }^{4}$

${ }^{4}$ G. Duse (1965) 'Le colonie degli anticolonialisti', Europa Libera, p. 19. 
Within the democratic anti-communist paradigm a reasoning developed whereby the condemnation of Soviet imperialism gradually shifted toward the denunciation of Western colonial regimes that still existed such as Portugal. ${ }^{5}$

The struggle against every form of despotism was indeed part of the anti-fascism of Catholic origin that had opposed communist totalitarianism and now coherently continued its battle against colonial regimes. This was clearly stated by Don Lorenzo Milani referring to the official Catholic doctrine that allowed for rebellion against unjust authority.

These reflections were given impetus by the encyclicals of Pope John XXIII and the positions taken by the Second Vatican Council toward decolonization. In the specific Italian situation, however, the revival of anti-fascism under way in the Catholic world played an important role in gaining awareness of inequalities in the balance of power between wealthy nations and the countries of the Third World. However, the problem of the violence that rebellion against unjust powers brought with it continued to remain in the shadows.

In the political arena Moro's Christian Democrat Party was engaged in enhancing the Resistance, especially in finding common ground for discussion with all the political forces involved in the creation of the Italian constitution with regard to the shared belonging of all Italians to the anti-fascist republic. Prominent in the attempts made to bring this about were the reflections of David Maria Turoldo, Ernesto Balducci, and Giorgio La Pira on anti-fascism as a shared ideal and a vehicle for peace among peoples in the face of the risk of nuclear catastrophe. Added to this was the favorable opinion expressed first by Pope John XXIII and later by Pope Paul VI on national liberation and the contribution made by Catholics to the Résistance against fascism and Nazism, by reviving the views of leading figures of that tradition such as Don Minzoni, Don Primo Mazzolari (who died in 1959), the Protestant theologian Dietrich Bonhoeffer, and the Jesuit Rupert Mayer. ${ }^{6}$

Reflection on the liberation movements in the Third World entailed, however, a twofold assessment. First of all, the differences in conditions in which political life took place in democracies and under authoritarian regimes led to the acknowledgment of the possible ineffectiveness of non-violent methods of struggle in the latter.

${ }^{5}$ Azione Sociale (1962) 'Si intensifica in Portogallo la crisi del regime', pp. 1-2.

${ }^{6}$ La Civiltà cattolica (1964) 'I cattolici e la Resistenza', p. 2. 
Second, it led to the acknowledgement that in the armed rebellion against colonial power there was the same moral principle that had justified the choice of Catholics to join the Resistance, in that it was conceived as legitimate defense and as a "response... to a foreign intervention considered unacceptable and which therefore can be described as aggression." 7

Therefore, acknowledgement of the independence movements in Africa and in Asia drove Catholics to denounce neo-colonialism, a new form of economic domination by countries from the West that had decided to continue to exploit the resources of former colonies. ${ }^{8}$ "Fascism of Affluence" was the term used by the New Left at the end of the decade, and it became the common term to refer to the hidden authoritarian essence of highly developed capitalist democratic societies, whose wealth depended on the supremacy of the West over the rest of the world. ${ }^{9}$

This was the reason some people even went so far as to form a positive interpretation of the well-read book The Wretched of the Earth by Frantz Fanon, the intellectual who in the 1960s had contributed most to reflection on colonialism and theorized about revolutionary violence being the only instrument for the liberation of colonial peoples.

The debate on capitalism and the Third World did not at first entail abandoning the anti-communist bias. Ernesto Balducci, for instance, wrote that it was the duty of Christians to denounce the "oppression of Budapest, Algiers, Suez."10 This sentiment of equal condemnation of Western imperialism and Soviet imperialism would continue in subsequent years too. With the outbreak of the war in Vietnam, Catholic magazines in fact featured articles denouncing both the destruction caused by the US war machine and the "cruelty of the Vietcong guerrillas," considered to be subordinates of Moscow's plans to expand its power.

However, the war in Vietnam divided the Christian anti-fascist world into those who supported the US intervention from an anti-communist viewpoint and those who were in favor of a peaceful solution to the conflict, while acknowledging however the legitimacy of the Vietcong

${ }^{7}$ S. Cotta (1997) 'La Resistenza armata: la questione morale' in G. De Rosa (ed.) Cattolici, Chiesa, Resistenza (Bologna: Il Mulino), pp. 95-96.

${ }^{8}$ Azione Sociale (1962) 'Sui resti del colonialismo una nuova civiltà', p. 7.

${ }^{9}$ A. Ercolani (1962) 'Il fascismo del benessere', Europa Libera, p. 11.

${ }^{10}$ E. Balducci (1958) 'Apertura', Testimonianze, p. 7. 
guerrillas. Painful soul-searching took place in the ranks of those favoring a peaceful solution regarding the nature of Western democracies and the reasons for the bond-the one between Italy and the United Stateswhich in the past had led to liberation from Nazi fascism, but now had difficulty finding a raison d'être, when considering the destruction the civilian population in Vietnam had suffered at the hands of the American army.

Similar tensions were to split Italian Catholicism, driven as it was by the positions taken by the Church of Rome to wonder about the future of the West in a world marked by wars and revolutions and by growing economic and social inequalities between countries in the north and south of the planet.

\section{The Dialogue Between Marxists and Catholics Following the Second Vatican Council}

The Second Vatican Council as is well known marked a turning point in the dialogue between Christians and communists - a turning point that only minority Catholic groups had tried to bring about in the preceding 20 years. The attempts to find agreement and solidarity "beyond the barricades put up in the past" with Marxists was not limited just to the Italian Catholic environment, but also occurred in other European countries, as shown by the conference on the relationship between Christianity and Marxism organized by the Catholic Society of Munich in Salzburg in the spring of $1965 .{ }^{11}$

Italian communists certainly did not let the offer of dialogue fall by the wayside, as evidenced by the direct support of Catholic-Communist intellectuals like Franco Rodano. The offer of dialogue appeared to be useful for the strategy begun by Togliatti after 1956. The 10th Italian Communist Party (PCI) Congress, held in December 1962, approved this line of action once and for all, and was reconfirmed by Togliatti during a rally in Bergamo on March 20, $1963 .^{12}$

Moreover, dialogue with the Catholics had been encouraged by the positions taken by the PCI regarding the problem of nuclear war. Togliatti had crossed swords with the Chinese Communist Party,

\footnotetext{
11 Testimonianze (1965) 'Salisburgo', p. 74.

${ }^{12}$ M. Gozzini (1964) 'I marxisti e la religione', Testimonianze, p. 65.
} 
claiming that revolutionary war on a global scale was unfeasible because of the irreversible destruction that would have resulted from a nuclear war between the two superpowers.

The link between the "dialogue" and the prospect of revolution, inherent in the Marxist-Leninist doctrine the PCI officially referred to, has not yet emerged in all its complexity and above all in its interaction with the theme of revolutionary violence felt by Catholics to be one of the biggest obstacles to discussions with communists.

After the crisis following the 20th Congress of the Communist Party of the Soviet Union and what had taken place in Hungary, nevertheless significant theoretical and doctrinal upheavals had taken place in international communism. Reflection on the destructiveness of nuclear weapons led to a critical revision of the Marxist-Leninist doctrine with regard to violence, especially in communist parties in the West and above all in the PCI. Regarding this Valentino Gerratana wrote:

Until now violence has been capable of having a progressive function in history because the destruction it causes, although increasingly extensive and catastrophic, has always been partial and could therefore stimulate new progress. But ever since the possibility of total destruction has arisen, violence has become just destructive violence, death which no longer produces new life, at least for our species. ${ }^{13}$

These were meaningful words toward rejecting violence as an instrument of emancipation. However, paradoxically, it ended up being precisely the peaceful solution to the Cuban missile crisis, which averted the nightmare of nuclear war between the two superpowers and restored legitimacy to those who did not intend to give up violence. Revolutionary movements throughout the world felt free to continue their fight, no longer haunted by the fear of provoking a planetary catastrophe.

The breakage of the monolithic position of the Soviet Union and the emergence of Maoist China increased the speed of the process of diversification of the strategies adopted by communist parties and Marxist movements to gain power in Third World countries. In Italy these changes strengthened the groups and movements that were forming

\footnotetext{
${ }^{13}$ V. Gerratana (1959) 'Con un piede nella nuova era e con l'altro nella preistoria', l'Unità.
} 
on the left of the PCI, ready to break with the party, because they were convinced that revolution was also possible in highly developed capitalist societies.

This ferment overlapped with the agitation caused by reports coming from Catholic missions in Africa, Asia, and Latin America, which were to cause an extraordinary stir thanks to new means of mass communication. Thanks to the first satellite television channels people all over the planet were able to see images and hear reports of the poverty and oppression of peoples in the Third World-situations that needed to be addressed therefore by the commitment of Catholics and all men of goodwill, as Pope John XXIII repeatedly stressed. ${ }^{14}$

Consequently, the Church increased its missionary activity in Africa, where the number of believers was on the increase and the conditions of poverty were intolerable. The Holy See was having to strike a delicate balance there: de-colonization had culminated in civil wars and a wave of violence against white minorities who were forced to emigrate.

The Vatican, however, struggled to identify its mission with the defense of Western interests, all the more so since new possibilities for evangelization were opening up thanks to agreements made with the new national states. It was necessary to safeguard the delicate balance between the need to strengthen the bonds with Catholic European nations, like Portugal, which still had a colonial empire and the need to establish relations with the countries that had just achieved independence.

\section{The Impact of the Populorum Progressio Encyclical}

In 1967 the worsening international situation-the outbreak of the Arab-Israeli conflict, the coup of the colonels in Greece, the military escalation in Vietnam, and the spiral of violence in Latin America-drove the new Pope Paul VI to place emphasis on the imbalances present in the power relations in the world.

According to Pope Paul VI, "Today the peoples in hunger are making a dramatic appeal to the peoples blessed with abundance." These words were written in the Populorum Progressio, the encyclical that denounced

14 l'Osservatore Romano (1960) 'Il sommo pontefice elogia le iniziative della: campagna mondiale contro la fame', l'Osservatore Romano, published 5 May 1960. 
widening the gap of inequality in the standards of living of nations - an abyss clearly perceived by the poor populations. ${ }^{15}$ The state of emergency, however, did not just regard the Third World.

Capitalist countries, too, needed to find a way of developing within their own boundaries that was not "mere economic growth." Capitalism, therefore, had become the harbinger of injustice and imbalance that was jeopardizing peace both within nations and among nations. In some regions of the world, like Latin America, unchecked liberalism had badly affected populations that were already tormented by outdated and feudal social structures.

Therefore, according to the encyclical, what was being created were "situations whose injustice cries to heaven. When whole populations destitute of necessities live in a state of dependence barring them from all initiative and responsibility, and all opportunity to advance culturally and share in social and political life, recourse to violence, as a means to right these wrongs to human dignity, is a grave temptation."16

Following this passage Pope Paul VI addressed the problem of armed revolution with no little caution:

We know, however, that a revolutionary uprising-save where there is manifest, long-standing tyranny which would do great damage to fundamental personal rights and dangerous harm to the common good of the country-produces new injustices, throws more elements out of balance and brings on new disasters. A real evil should not be fought against at the cost of greater misery. ${ }^{17}$

This was a decisive passage that emboldened many Third Worldism Catholic circles to radicalize their positions. Progressive Catholic magazines, such as Questitalia, Testimonianze, il Gallo, Note di cultura, and il Tetto, added yet more fuel to the fire of these tensions.

Environments in which religious sensibility was pre-eminent argued that Christian parties in Italy and Europe had neglected the task of building a "new Christian civilization" and had identified with the

${ }^{15}$ Lettera enciclica del sommo pontefice Paolo PP. VI "Populorum Progressio" sullo sviluppo dei popoli, § 1 .

16 ivi., $\S 30$.

17 ivi., $\S 31$. 
capitalist attitude of society. It was claimed that such a path had been taken long ago at the time secularization took hold and the crisis of faith in industrialized countries.

According to the magazine Testimonianze, for instance, what had ended was a long process that had begun with the Protestant Reformation, continued with the Enlightenment and the French Revolution, and culminated in the building of a consumer civilization.

This judgment reflected the interpretative pattern of a Catholicism that was uncompromising toward modernity, which both before and after the Second Vatican Council began to spread and gained approval even outside traditionalist currents. Suffice it to say that one of the most active Catholic groups in Milan during the student protest of 1968 took its name from Georges Bernasos, known for his condemnation of Francoism and being the author of a heated debate against capitalist society and democracy.

Pope John XXIII had openly taken up a position against the "prophets of doom," the bearers of an apocalyptic view of modern times. There had also been the theological reflection formed in France in the 1950s, through the work of Pierre Theilard de Chardin, Emmanuel Mounier, Jacques Maritain, and the magazine Esprit, on the relationship between faith and contemporary society, whose stimuli were at first opposed and then acknowledged by the Second Vatican Council, thereby influencing Italian and Latin American theology in the years to follow.

The problem of the relationship with modernity remained however unresolved, despite indications contained in the Gaudium et Spes Pastoral Constitution regarding the role of the Church in the contemporary age and the impact that this had on the various Catholic environments (in Testimonianze, for instance, which gave up its original critical position). The Second Vatican Council in fact had left a difficult legacy around which the anxieties and uncertainties that marked the postconciliar period simply grew and increased. The crumbling of farming society, urbanization processes, internal emigration, and the resumption of social conflict had in fact thrown the Catholic world into turmoil, depriving it of its traditional points of reference.

In some environments these upheavals led to radical criticism of the present. The inequalities of affluent society became intolerable, as did the conditions of poverty that burdened many areas of the planet, and 
both were ascribed to the capitalist economic system. The consumer and abundance culture was thus experienced as a trauma, a veritable sin to expiate.

In this way a particularly pessimistic, at times even apocalyptic, view of reality became widespread. The more extremist groups soon accused the ecclesiastical hierarchies of betraying the real message of the Second Vatican Council, which focused on reconciliation of the Church with the poor. This was the step that prompted them to approach the revolutionary currents of Marxism that were now fortified by the successes of guerrilla warfare in Africa, Asia, and Latin America and by the theoretical processing that had been carried out by the New Left in Europe and North America.

In fact concern regarding the poverty afflicting the peoples of $\mathrm{t}$ he Third World soon joined up with discomfort regarding the conditions of poverty in which large portions of the populations of more advanced industrial societies continued to live. At that point people began wondering whether the experiments to find political and theological solutions carried out by Christians in Latin America could be used in Europe too.

This issue was particularly strongly felt in Italy where signs of a decline in the development enjoyed in the preceding years had begun to be evident. The crisis had in fact revealed differences in levels of wealth within the country and the social costs of the "economic miracle," as a result of the emptying of the farming countryside and rapid industrialization and urbanization, especially in the Center-North.

In the radical Catholic circles that had been created in years immediately following the Second Vatican Council there was a widespread belief that the negative economic trend was the first sign of a more serious and profound crisis, destined to get worse, and to involve a growing number of the population.

In reality it was an opinion that was only partially true because, while it took into consideration the consequences of imbalances that had accumulated over time, it did not take into account the profound changes taking place in the nation's social and economic structures. The inequalities had not disappeared-far from it-but highly developed capitalist societies had social tensions and forms of conflict that were entirely different and until then unknown. 
The great political cultures of the country-Catholic, communist, stakeholder-republican, and socialist-had split into various internal factions when it came to interpreting these changes. On the left the heady economic development had given rise to heated debate on Italian capitalism. Among the socialists there were discussions about structural reforms and at the Congress of the Gramsci Institute on capitalist trends, held in March 1962, there were various speeches by Giorgio Amendola, Bruno Trentin, Pietro Ingrao, and Lucio Magri-all of which indicated just how much widespread uncertainty there was about the nature of the transformations that had taken place.

The most progressive parts of the reformist alignment-the communist left, and the pro-worker intellectual and critical Marxist currentsnevertheless shared a somewhat similar opinion in acknowledging the fact that in capitalism, contrary to what Marxist doctrine professed, an unprecedented level of development had taken place; however, they differed radically in their conclusions. The reformists considered it necessary to rethink the role of the State in the promotion of social equality and to redesign the relationship with the market economy; the communist left, instead, thought it necessary to revisit the concept of revolution in a society, like the consumer society, which through the increase in wages and the spread of prosperity aimed to integrate the working class in the capitalist system.

With respect to this reference framework, the reflection of radical Catholicism occurred in two stages and featured an ideological and unilateral anti-capitalism. What initially prevailed were the pauperism theories that insisted there would be imminent impoverishment of Western nations as a result of exploitation, just as was happening in the Third World. It was only later that an awareness grew regarding the fact that the consumer society posed a series of completely new problems, not only of a social nature but also of an anthropological and religious nature.

The prospect of gradual pauperization led them to consider the revolutionary path that Christians in Latin America experimented with might be possible in Italy too, although until then it had only been considered applicable by virtue of the extraordinary conditions of poverty and oppression of the context itself. 
Similar conclusions were also reached by some theorists on the extreme left. In the first half of the 1960s pro-worker theses had in fact met with much reservation by the rest of the radical left, who were instead strongly attracted to the Cuban Revolution model. During the agitated phase of the birth of the New Left, before it settled at the end of the decade, there was a long discussion that wentfrom one extreme to another and even at a certain point brought backin vogue theories on the collapse of capitalism of a Third International tradition.

Leo Huberman and Paul M. Sweezy, for example, two leading representatives of the Anglo-Saxon New Left, even wrote about an "internal colonial war" in the United States. ${ }^{18}$ Taking their cue from the riots in the black ghettos the two authors believed that the racial character of the protest movements was secondary to the classist character of the clashes, which according to them were destined to spread to the rest of the impoverished population, regardless of the communities they belonged to.

The United States was therefore seen as an advocate of a twofold colonial war: one abroad with the armed forces busy in Vietnam and its support for authoritarian regimes in South America, and another inside its own country against the North American working class. During the same years Jean-Paul Sartre spoke of capitalism as a single colonial system operating in European countries and in developing countries, seeing an analogy between the beginning of working class clashes in France and the struggles for decolonization.

In his foreword to Fanon's The Wretched of the Earth he wrote:

We in Europe too are being decolonized: that is to say that the settler which is in every one of us is being savagely rooted out». In his view, revolutionary violence had a liberating function and at the same time one of redemption, because it would have freed the peoples of the Third World and redeemed the Europeans themselves. This reasoning was then brought

${ }^{18}$ L. Huberman and P. M. Sweezy (1968) La controrivoluzione globale. La politica degli Stati Uniti dal 1963 al 1968 (Torino: Einaudi), pp. 52-67. 
to its extreme consequences. He concluded: «to shoot down a European is to kill two birds with one stone, to destroy an oppressor and the man he oppresses at the same time. ${ }^{19}$

Stretching reality ideologically in this remarkable way was no less effective in welding into a single Welthanschauung ("worldview") the social tensions in advanced societies together with anti-imperialist struggles. This view, which presented protest movements as a moment in the process of "internal decolonization" within capitalist societies, corresponded to the sensibility of radical Catholic environments, where there was a widespread temptation to imitate the revolutionary movements of the Third World.

\section{Conclusions}

As already mentioned, in 1967 escalation of the war in Vietnam, the Arab-Israeli Six-Day War, and the spread of guerrilla movements in Latin America prompted groups on the extreme left and the student movement to reformulate the theme of the struggle against US imperialism as it had been traditionally set out by workers' movements and the Communist Party.

A great deal of time and space was given over at that time to exalting violence as something that might speed up economic and social processes. The question certainly was not new (quite the opposite-it had been present throughout the history of Marxism), but its recurrence was a turning point because the balance of terror imposed by the nuclear weapons of the United States and the Soviet Union had driven the extreme left to believe that revolution in Europe was not possible due to the risk of causing a catastrophic chain reaction at the international level.

With the increasing number of wars and crises that since the second half of the 1950s had involved Asia, Africa, the Middle East, and Latin America this conviction faded away. In particular, the solution

${ }^{19}$ J.-P. Sartre (1962), preface to F. Fanon I dannati della terra (Torino: Einaudi), pp. 17-19. 
of the Cuban missile crisis in October 1962 showed that antagonism between the two superpowers would not necessarily end in a nuclear war. Therefore, in the second half of the 1960s the student protests in Europe and in North America went hand in hand with the belief that revolution was possible even in the heart of the West.

Translations of texts on the Algerian Revolution, the Cuban Revolution, and on the Vietnamese guerrillas led to the belief that the overwhelming superiority of the superpowers in terms of technology and military capacity was not a sufficient deterrent to stem the tide of all the revolutionary movements together. Hence the belief that these needed to be coordinated thereby giving life to a new working class internationalism to destroy the peaceful co-existence of the United States with the Soviet Union and at the same time promote a single insurrectional strategy on a global scale: "Create two, three... many Vietnams ..." as Ernesto "Che" Guevara wrote in his political testament.

The consequences of such theories within Marxism couldn't not be felt. Hannah Arendt was one of the first to notice this contradiction. As early as 1970 the German philosopher had noticed the great importance attached to violence by the nascent extra-parliamentary left:

The more doubtful the outcome of violence in international relations, the more it has gained in reputation and appeal in domestic affairs, specifically in the matter of revolution. The strong Marxist flavor in the rhetoric of the New Left coincides with the steady growth of the entirely non-Marxian conviction, proclaimed by Mao Tsetung, "Power grows out of the barrel of a gun." To be sure, Marx was aware of the role of violence in history, but this role was to him secondary; not violence but the contradictions inherent in the old society brought about its end. The emergence of a new society was preceded, but not caused, by violent outbreaks, which he likened to the labor pangs that precede, but of course do not cause, the event of organic birth.

Recovering this dimension of the intellectual debate within Italian Marxism would help to better understand the more profound demands of that period. ${ }^{20}$ 


\section{BiBLIOGRAPHY}

Arendt, H. (1996) Sulla violenza (Parma: Guanda).

Brundenius, C. and Weeks, J. (2001) Globalization and Third World Socialism: Cuba and Vietnam (London and New York: Palgrave Macmillan).

Burke, E. (1998) 'Orientalism and World History: Representing Middle Eastern Nationalism and Islamism in the Twentieth Century', Theory and Society, 4, 489-507.

Byrne, J. J. (2016) Mecca of Revolution: Algeria, Decolonization and the Third World Order (Cambridge: Cambridge University Press).

Calchi Novati, G. P. (1979) Decolonizzazione e terzo mondo (Rome: Laterza).

Carel, I., Comeau, R., and Warren, J.-P. (2013) Violences politiques: Europe et Amériques, 1960-1970 (Montreal: Lux Editeur).

Cornelißen, C., Mantelli, B., and Terhoeven, T. (2012) Il decennio rosso. Contestazione sociale e conflitto politico in Germania e in Italia negli anni Sessanta e Settanta (Bologna: Il Mulino).

Corradi, C. (2011) Storia dei marxismi italiani (Rome: manifestolibri).

Cotta, S. (1997) 'La Resistenza armata: la questione morale’ in G. De Rosa (ed.) Cattolici, Chiesa, Resistenza (Bologna: Il Mulino).

De Giuseppe, M. (2012) 'Il «Terzo mondo» in Italia. Trasformazioni di un concetto tra opinione pubblica, azione politica e mobilitazione civile (19551980)', Ricerche di Storia Politica, 1, 29-52.

De Giuseppe, M. (2016) 'Cattolici italiani e l'America Latina nei lunghi anni settanta. Tra Terzo mondo e altro Occidente', Italia Contemporanea, 280, 4065.

Dirlik, A. (1983) 'The Predicament of Marxist Revolutionary Consciousness: Mao Zedong, Antonio Gramsci, and the Reformulation of Marxist Revolutionary Theory', Modern China, 2, 182-211.

Gentili, D. (2012) Italian Theory. Dall'operaismo alla biopolitica (Bologna: Il Mulino).

Hopkins, A. G. (2008) 'Rethinking Decolonization', Past \& Present, 211-47.

Huberman, L. and Sweezy, P. M. (1968) La controrivoluzione globale. La politica degli Stati Uniti dal 1963 al 1968 (Torino: Einaudi).

Jobs, R. I. (2009) 'Youth Movements: Travel, Protest, and Europe in 1968', The American Historical Review, 2, 376-404.

Kruijt, D. (2008) Guerrillas: War and Peace in Central America (London: Zed Books).

Martelli, A. (2008) L'altro atlantismo. Fanfani e la politica estera italiana 19581963 (Milano: Guerini e Associati).

Marzano, A. (2016) 'Il mito della Palestina nell'immaginario della sinistra extraparlamentare italiana degli anni settanta', Italia Contemporanea, 280, 15-39.

Mastrofini, F. (2006) Geopolitica della Chiesa cattolica (Rome: Laterza). 
Melloni, A. (2000) L'altra Roma. Politica e S. Sede durante il concilio Vaticano II (1959-1965) (Bologna: Il Mulino).

Menozzi, D. (1980) Chiesa, poveri, società nell'età moderna e contemporanea (Brescia: Queriniana).

Mugnaini, M. (2006) 'La diplomazia di Paolo VI di fronte ai problemi della guerra e della pace' in L. Goglia, R. Moro, and L. Nuti (eds.) Guerra e pace nell'Italia del Novecento (Bologna: Il Mulino), pp. 403-35.

Panvini, G. (2009) Ordine nero, guerriglia rossa. La violenza politica nell'Italia degli anni Sessanta e Settanta (Torino: Einaudi).

Panvini, G. (2011) 'La nuova sinistra' in M. Gervasoni (ed.) Storia delle sinistre nell'Italia repubblicana (Marco: Lungro di Cosenza).

Panvini, G. (2014) Cattolici e violenza politica. L'altro album di famiglia del terrorismo italiano (Venezia: Marsilio).

Pellettier, D. and Schlegel, J. L. (2012) A la gauche du Christ: Les Chrétiens de Gauche en France de 1945 à nous jours (Paris: Seuil).

Pirelli, G. (ed.) Fanon (1971) Decolonizzazione e indipendenza. Violenza, spontaneità e coscienza nazionale (Torino: Einaudi).

Pons, S. (2014) The Global Revolution. A History of International Communism (1917-1991) (Oxford: Oxford University Press).

Pozzi, D. (2010) 'Entrepreneurship and Capabilities in a "Beginner" Oil Multinational: The Case of ENI', The Business History Review, 2, 253-74.

Rapoport, D. C. (2004) 'Modern Terror: The Four Waves' in A. K. Cronin and J. M. Ludes (eds.) Attacking Terrorism: Elements of a Grand Strategy (Georgetown: Georgetown University Press), pp. 46-73.

Rothwell, M. (2009) 'Transpacific Revolutionaries: The Creation of Latin American Maoism' in K. Dubinsky, C. Krull, S. Lord, S. Mills, and S. Rutherford (eds.) New World Coming. The Sixties and the Shaping of Global Consciousness (Toronto: Between the Lines), pp. 106-14.

Ruth Hosek, J. (2009) 'Interpretations of Third World Solidarity and Contemporary German nationalism' in K. Dubinsky, C. Krull, S. Lord, S. Mills, and S. Rutherford (eds.) New World Coming. The Sixties and the Shaping of Global Consciousness (Toronto: Between the Lines), pp. 68-76.

Saresella, D. (2011) Cattolici a sinistra. Dal modernismo ai giorni nostri (Rome: Laterza).

Sartre, J.-P. (1962) preface to Fanon, F., I dannati della terra (Torino: Einaudi). Varsori, A. and Romero, F. (2005) Nazione, interdipendenza, integrazione: le relazioni internazionali dell'Italia (1917-1989) (Roma: Carocci). 